Historic, Archive Document

Do not assume content reflects current scientific knowledge, policies, or practices. 



\section{DAHLIAS for 1921}

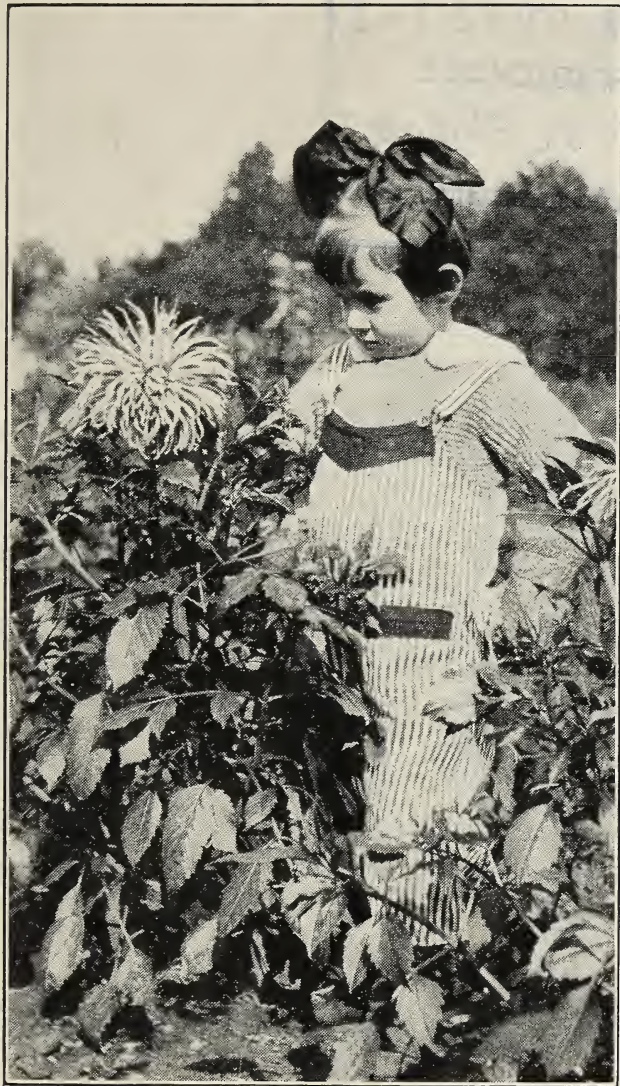

Cactus Dahlia PIERROT

This photograph made about October first shows the quality of the flower. Grown, without special attention, from a little green plant, set out in July

\section{A. W. B EE B E MAPLEWOOD NEW JERSEY}

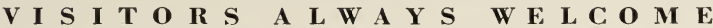





\section{CULTURE OF DAHLIAS}

T $\mathrm{N}$ presenting this catalogue for your consideration I take this means of calling attention to the advantages of using green plants instead of tubers, particularly when growing Dahlias for exhibition.

When growing from tubers it will frequently be found -indeed I consider it the greatest single cause of failure-that during dry weather in July and August, when the plants have made considerable growth, the roots are unable to get sufficient moisture to maintain the older growth and at the same time form the new, soft, green growth so essential for first-class blooms. In such cases progress stops, and so much time is required to form the new growth after pruning and watering that the crop of flowers may be too greatly delayed.

Green plants set out during June will make only a moderate growth by the middle of summer, and with a minimum of care can be kept in vigorous condition during the entire season, starting to flower around the first of September and being at their best the latter part of the month, just in time for exhibiting and also at the time of the year when in their prime for cutting.

Many of those who visited my place last fall will probably be surprised to learn that the best of my display 
was secured from green plants set out during June and early July.

For the convenience of those who desire to grow the very finest dahlias I have arranged to furnish thrifty, well-rooted green plants from two-inch pots; these will be available from about May 20th to June 15th. Many of the latest and best novelties, as well as the choicest of the standard varieties, are in the list, so that ample choice is assured and as inferior kinds have been eliminated you can rely on the varieties offered.

Retail prices include parcel post or express charges to any point in the United States or Canada.

Please remit in full when ordering. 


\section{DAHLIAS}

Aida (Decorative). Dark maroon, large, perfect flowers carried high above the foliage on rigid upright stems. A recent California introduction of considerable merit. Tubers, each, 50 cents; well rooted plants, each, 35 cents.

Alabaster (Cactus). From Stredwick, who says: "A flower of purest white, and a variety that has come to stay. The blooms are of large size, and just sufficiently incurved in form to show to adrantage when exhibited. The plants are sturdy and dwarf and carry the flowers boldly on stout, erect stems. We predict that this will supersede all other white cactus, it being one of the most genuine varieties we have ever raised." Tubers, each, $\$ \mathbf{1 . 0 0}$; well rooted plants, each, 75 cents.

Amber Queen (Peony). One of the newer Dahlias of the English peony type. Amber shaded orange, large and very distinct and of a color that is quite different from nearly every other variety. Tubers, each, 75 cents; well rooted plants, each, 50 cents.

Attraction (Hybrid Cactus). A beautiful hybrid cactus that attracts the attention of every one. The flowers measure over six inches in diameter and are composed of gracefully arranged curled or twisted petals of a lively yet soft, silvery lilac rose with white suffusion. This variety has long, very stiff stems and keeps excellently when cut. Tubers, each, 75 cents; well rooted plants, each, 50 cents.

Avalanche (Peony). Large flowers of pure white carried on stiff stems and with full, high centers. Very good. Tubers, each, 75 cents; well rooted plants, each, 50 cents.

Australian (Cactus). Rich, velvety, purplish maroon. Large blossoms supported on stiff stems. Tubers, each, 50 cents.

Basilisk (Cactus). A very fine, bright, scarlet cactus Dahlia of the English type; large, early and quite incurved. Tubers, each, 50 cents. 
Beloit (Decorative, but sometimes classed as a $\mathrm{Hy}-$ brid Cactus). Dark, glowing, purplish, crimson flower of good substance. Tubers, each, 35 cents.

Bertha Von Suttner (Peony). Flowers of exquisite form and of a lovely, true salmon color ( $\mathrm{R}$ Shrimp pink). Tubers, each, 50 cents; well rooted plants, each, 35 cents.

Bianca (Hybrid Cactus). Uniformly large, six inches and over in diameter, with moderately broad petals forming a splendid symmetrical and graceful flower of a soft, pleasing shade of mauve-pink passing to white at the tips. One of the best for cutting. Tubers, each, 50 cts.; well rooted plants, each, 35 cts.

Bloemhoven (Peony). A splendid, exceptionally free flowering Dahlia of a pleasing shade of lilacrose. Tubers, each, 50 cents.

Break o' Day (Hybrid Cactus). Clear, sulphur yellow, shading to a creamy white at the tips of the petals. A variety for which the demand exceeds the supply. Well rooted plants, each, \$1.25.

British Iion (Cactus). Another highly interesting Stredwick introduction. The blooms are composed of a great number of long, twisted and curling petals, not particularly narrow, so that the flowers present a massive appearance. The color is peculiar, yellowish for the most part, but burnished with red, almost it might be termed, tawny in color. Plants strong and produce huge flowers. A few tubers, each, \$1.00; well rooted plants, each, 75 cents.

Cambria (Decorative). One of the finest Dahlias ever produced. A big, heavy pink flower, shading to white and held well up on long, stiff and perfectly straight stems. Plants only, each, \$1.25.

Copper (Decorative). Beautiful because of its odd coloring of copper shading to bronze. Tall growing plants with long, straight flower stems. Strong, well rooted plants, each, 50 cents.

Cream King (Decorative). An incomparable Dahlia that is a favorite wherever grown or exhibited. The coloring is different, a soft cream as the name indicates. The stem is very long, which makes it 
excellent for cutting, and as for size-well it is simply immense, which makes it a favorite for exhibiting. A few roots, each $\mathbf{\$ 1 . 0 0 ;}$ well rooted plants, each, 75 cents.

Creation (Decorative). Medium sized, full flowers, held well up on strong, stiff stems. In color a beautiful shade of light cherry red, becoming still lighter toward the edges and tips of the petals and as the flowers open. Tubers, each, 75 cents; well rooted plants, each, 50 cents.

Diana (Hybrid Cactus). A Dahlia that it is a real pleasure to grow and one of my favorites. Crimson with violet reflex, but the colors are so soft and so beautifully blended that the effect is more that of a very soft and very rich ox-blood red. Good stems. Tubers, each, 75 cents; strong, green plants, each, 50 cents.

Dr. Tevis (Decorative). A magnificent blossom of a blend of copper, old rose and old gold. Immense flower with the best possible stem, and a Californian which it is a pleasure to offer. Well rooted plants only, each, \$1.00.

Dr. Tyrrell (Decorative). An Eastern Dahlia of merit. Color a deep, rich bronze. Tubers, each, 35 cents.

Dreadnought (Cactus). Deep crimson maroon, an excellent dark-colored variety. Tubers, each, 35 cents.

Farle Williams (Decorative). New, crimson tipped with white. Stock limited and I can offer only a few green plants. Well rooted plants, each, \$2.50.

Flsa (Peony). One of the best white Dahlias of the peony type that has been brought out; pure white with a big yellow center. A free bloomer with good stems. A few tubers, each, 75 cents; green plants, each, 50 cents.

Ftendard De Iyon (Hybrid Cactus). From the French hybridizer Rivoire. Color a peculiar and beautiful shade of purplish crimson. Petals loose and large and stem good. Strong plants, each, 50 cents. 
Fantastique (Peony). Flowers semi-double with irregular cup-shaped petals, curled and twisted in a manner that gives somewhat the appearance of an Orchid. Color a deep wine crimson, tipped and bordered with white. Long strong stems. Well rooted plants only, each, $\$ \mathbf{1 . 0 0}$.

Futurity (Decorative). To my knowledge, the most beautiful Dahlia of its coloring, a deep old rose. The flowers are medium to large and regularly formed. Stems are good, carrying the blossoms well above the foliage, so that this variety is always in demand for cutting and it is equally good for exhibition. Tubers, each, 75 cents; strong plants, each, 50 cents.

F. W. Fellows (Cactus). One of the finest English cactus. The flowers are of immense size and are composed of a great number of long, narrow, nearly straight petals. The color is unusual, being a brilliant terra cotta or orange scarlet. Stems are long and quite stiff, making it one of the best of the type for cutting and for exhibiting. Tubers, each, 75 cents; well rooted plants, each, 50 cents.

Geisha (Peony). Showy and attractive, unique in form and color; the richly colored flowers consisting of peculiarly twisted and curled petals of an effective, rich combination of scarlet and gold. Tubers, each, 75 cents; well rooted plants, each, 50 cents.

General Joffre (Hybrid Cactus). Large flowers of a deep maroon crimson, edged with scarlet, a very pleasing shade. Blooms held erect on stiff stems often 18 inches long. Green plants, each, 75 cents.

General Sir Douglas Fraig (English Cactus). Originated by Stredwick, who says: "The flowers are of perfect form, the slender tubular florets incurving and twisting irregularly and making ideal exhibition flowers of good size. The color, too, is second to none, being a lovely combination of tints of pink, grading from almost white to deep, then to lighter again." A few field grown roots, each, $\$ 1.00$; strong plants, each, 75 cents.

George H. Mastick (Peony). Large flowers of many wavy petals full to the center on long, strong stems. 
Color is blackish maroon with currant tips to outer row of petals. As the flower ages, it shows a yellow disk around the center and changes color to a dark crimson. Remarkably free bloomer and beautiful at all stages. Well rooted plants, each, \$1.00.

George walters (Hybrid Cactus, but sometimes classed as a Decorative). Always good, always big and always full of flowers; one of the kind that it is a pleasure to grow and to offer, and one that should be first choice for garden or exhibition. Color salmon with a golden sheen and shading to orange yellow at the center. Strong field grown roots, each, \$2.00; thrifty green plants, each, $\$ \mathbf{1 . 0 0}$.

Glory of reyden (Peony). A Holland Dahlia of an attractive shade of red, worth trying. Green plants, each, 50 cents.

Golden Gate (Hybrid Cactus). A large flower of a bright golden yellow and having thick, heavy petals which last well when cut. Field grown tubers, each, 35 cents.

Fampton Court (Peony). An English flower that is worthy of note because of its long, stiff stem. The flower itself is of large size, and in color is an exceedingly effective bright mauve pink. Strong field grown roots, each, 35 cents.

Herbert Raby (Cactus). An immense crimson purple flower composed of only one or two rows of incurved and twisted petals arranged about a big yellow center. Quite different and well worth a trial. Tubers, each, 50 cents.

Hochsai (Decorative). A Holland Dahlia, orange, splashed and marked with scarlet. Very full and regular flowers on stiff stems; should be disbudded freely, and it will then give excellent results. Field grown roots, each, 50 cents.

Holman Hunt (Peony). One of the best dark colored flowers of this type. Flowers are large, of a dark crimson shaded with scarlet and are freely borne on long stems. Tubers, each, 75 cents; well rooted plants, each, 50 cents. 
Hortulanus Fiet (Decorative). Salmon rose, shading to old gold in center. Immense flowers on long strong stems. Roots, each, 75 cents; green plants, each. 50 cents.

Insulinde (Decorative). Am almost tempted to describe this as the finest Dahlia I have ever grown, certainly it is one of the very best that has ever come to my notice. For those desiring an immense buff-orange flower, lightly marked with scarlet on a few of the center petals, and set squarely on top of a stem almost as long and as stiff as a cane, I do not believe it can be excelled. Field grown roots, each, $\$ 2.50$; strong green plants, each, $\$ 1.00$.

Irresistible (Cactus). Large incurved flowers, yellow, lightly suffused rose, giving the effect of a delicate salmon pink. Field roots, each, 50 cents.

Ivory white (Cactus). The best white exhibition cactus. Flowers large, much on the style of F. W. Fellows, and composed of a large number of long slim petals giving plenty of substance. Green plants, each, 50 cents.

Jane Selby (Decorative). Large flower of delicate mauve pink, of great depth and substance. Good stem and excellent as a cut flower. One of the most consistent prize winners ever introduced. Well rooted plants, each, $\$ 1.00$.

Jessie M. Williams (Peony). A beautiful, soft, dove color suffused with lilac rose. The flower is very large and fluffy and a delight to the eye. The excellent stem and lasting quality make it valuable for cutting. Well rooted green plants, each, $\$ \mathbf{1 . 5 0}$.

J. M. Goodrich (Decorative). A medium to large flower of an exquisite shade of rosy salmon. Field roots, each, 35 cents.

John Riding (Cactus). Incurved, interlacing flowers of a deep, rich crimson color. Field grown roots, each, 35 cents.

Jonkheer Boreel Van IIoogenlanden (Decorative). A Dahlia that is as good as the name is long. Solid, deep old gold on long stiff stems. Strong field grown tubers, each, $\$ 1.00$; well rooted plants, each, 75 cents. 
Justice Bailey (Hybrid Cactus).

A Colorado variety that has considerable merit. Color rich, glowing pink, shading a little lighter toward the center. Large flowers on good stems. Strong green plants, each, 50 cents.

Kalif (Hybrid Cactus). A wonderful and beautiful flower, frequently measuring over nine inches in diameter and borne on a long and strong stem. Particularly good as a cut flower. Color pure scarlet. Strong roots, each, 75 cents; well rooted plants, each, 50 cents.

Kiffin Rockwell (French Decorative). Very, very large full flowers. Outside petals rich bronze. Inside petals bright golden yellow, sometimes tipped white. A rare and beautiful Dahlia. Well rooted plants, each, $\$ 2.50$.

King Albert (Decorative). A big, rich, deep violet flower, much the shape of Insulinde, though of quite different color; full to the center with plenty of long and broad curled and wavy petals. Good stems. Field grown roots, each, 75 cents; green plants, each, 50 cents.

King of the Autumn (Decorative). Medium to large sized flowers of an exquisite buff-orange color with a suffusion of rose. This variety has the best stem I have ever seen, it being quite common to cut flowers with stems three feet or more in length and perfectly stiff and straight. The flowers when true to type are wonderful, though this variety will sometimes have double, semi-double and almost single flowers on the same plant. Strong field grown roots, each, 75 cents; well rooted plants, each, 50 cents.

Iady Alla (Peony). Introducer's Description-Color is a bright scarlet. Long, strong stems carrying lower well above foliage. Large flower and a good keeper. Fragrant and more fragrant as a cut flower than on the bush. Green plants, each, $\$ \mathbf{\$ 1 . 0 0}$.

Ia Favorita (Hybrid Cactus). This splendid new variety resembles in form, type, growing and flowering qualities the yellow Dahlia, Mrs. Richard 
Lohrmann, except in color, which is a beautiful brilliant salmon, shading from a dark reddish salmon in the center to salmon-pink at the twisted points of the petals. Form perfect, showing a full center even late in the season. A first class cut flower variety, each bloom being carried on a strong stem. A few roots, each, \$2.50; well rooted plants, each, \$1.50.

Ie Collosse (Show). An exceptionally popular Dahlia, distinguished for its enormous size, being one of the largest grown. Color a soft brick red. A deep, massive flower of globular shape; petals are cup-shaped and placed with exact regularity. Field grown tubers, each, $\$ \mathbf{1 . 0 0}$; Green plants, each, 75

\section{cents.}

IFO XIII (Peony). An extremely large Holland variety that is always good. Color clear bright yellow. Stem very good, too, and it is a constant bloomer. Well rooted plants, each, 50 cents.

Ieviathan (Decorative). A monster decorative with blooms carried on stout stems, perfectly erect. The florets are broad at the base, reflexed and narrower at the points. Flowers massive and solid. Color orange-scarlet throughout. Green plants, each, \$1.00.

Liberty (Peony). A free bloomer of a brilliant coral red. Stems are exceptionally long and rigid, and it is an excellent variety for either exhibition or cutting. Strong tubers, each, 75 cents; well rooted plants, each, 50 cents.

Madonna (Decorative). Large white, with delicate blending of lavender pink. Long stems, a good cut flower variety which, when disbudded, will produce flowers eight inches or more in diameter. Field grown roots, each, 35 cents.

Mammoth (Decorative). An enormous flower of soft scarlet, shading lighter toward the edges and tips of the petals. Field grown roots, each, 50 cents; green plants, each, 35 cents.

Marguerite Bouchon (Cactus). A well known straight petalled cactus. Brilliant rose heavily tipped with white. This variety gives best results 
when grown from green plants. Field grown roots, each, 75 cents; well rooted plants, each, 50 cents.

Mayday (Peony). A striking English variety of merit. Petals marked lengthwise with various proportions of rose, white and sometimes yellow. Field grown roots, each, \$1.00; green plants, each, 75 cents.

Melody (Cactus). One of the most distinct, color being clear yellow for half the length of the florets, balance pure white. Green plants, each, 50 cents.

Millionaire (Decorative). Probably the best and certainly the best-known introduction of Mr. Geo. L. Stillman. One of the largest varieties grown. Color lavender shading to white. Field roots, each, \$2.50; green plants, each, $\$ 1.00$.

Mrs. Jack Green (Peony). A very large and full flower on a strong stem. Color a beautiful shade of rich scarlet. Well rooted green plants, each, 50 cents.

Mrs. J. C. Vaughan (Hybrid Cactus). A rather dwarf growing variety which produces an abundance of moderately large flowers on excellent long stems. Color a lively lemon yellow. Magnificent for cutting. Tubers, each, 50 cents; green plants, each, 35 cents.

Mrs. Jessie I. Seal (Peony). The largest flower of its coloring, which is a wonderful old rose with golden shadings. The stem is particularly long and the blossom is borne well above the foliage. An all around good Dahlia. Well rooted green plants, each, $\$ 1.00$.

Mrs. Margaret stredwick (Cactus). This, I believe, to be one of the most perfect incurved flowers introduced. The coloring is a combination of tints of pink, softening and deepening at tips and base. Very desirable. Well rooted plants, each, $\$ \mathbf{1 . 0 0}$.

Mrs. Richard Iohrmann (Hybrid Cactus). A pure golden yellow of immense size with broad curly petals; flowers high above the foliage on long upright stems. Excellent cut flower and one of the best yellow Dahlias. Green plants, well rooted, exch, $\$ 1.00$. 
Mrs. R. R. Strange (Decorative). One of the best of the California novelties. Particularly desirable for its wondrous coloring of burnished copper with faint shadings of old rose and old gold. Flowers large and stems good. Green plants, each, \$2.00.

Mrs. T. A. Munro (Hybrid Cactus). A giant flower; color amber shading to old gold and the outer petals tinted brown. Well rooted plants, each, 75 cents.

IIrs. Warnaar (Hybrid Cactus). A splendid exhibition and cut-flower variety of a creamy white with a faint suffusion of apple blossom pink. Flowers uniformly large, usually over eight inches in diameter and on strong, stiff stems; petals long and peculiarly twisted and curled. Field grown roots, each, 75 cents; green plants, each, 50 cents.

Nibelungenhort (Hybrid Cactus). This is always greatly admired, flowers from seven to eight inches across, composed of rather broad, curled and twisted petals of a beautiful shade of old rose with goldenapricot suffusion. Very free flowering. Tubers, each, 50 cents.

Niagara (Peony). Introducer's description- "This Dahlia has been described as the exact shade of old Genoese velvet; anyway, it is a lovely, odd shade of red. But its great charm is its unique formation. The tiny, curling inner petals are so numerous as often to completely hide the yellow center. It bears a wealth of big blooms on splendid, upright stems throughout the entire season." Well rooted plants, each, $\$ 1.00$.

Orient (Peony). A new and brilliant combination of scarlet and yellow. Long, slender, pointed petals and excellent stems. Green plants, each, $\$ \mathbf{1 . 0 0}$.

Osam Shudow (Decorative). The most prominent feature of this Dahlia is its formation. The big, heavy, loose petals produce a flower more like a gigantic rose than a Dahlia. The color is old rose slightly suffused with lilac and shading to yellow at the center. Flower stems are long, thick and heavy and the blossoms come well above the foliage. Well rooted plants, each, $\$ 2.50$. 
Pacific Glow (Peony). This Dahlia, though not well known, is one of the largest of its type, having taken a prize at one of the California shows because of its size. A really excellent variety that is well worth a trial. Color a beautiful creamy pink, stems good. Green plants, each, \$2.00.

Pierrot (Cactus). A unique and striking novelty in color, and of unusual grace and refinement in form, being composed of very long, tubular narrow petals which are of a deep amber color, usually showing white tips, but even when it comes off a self color without these tips it possesses an individual refinement different from all other sorts. A wonderful exhibition flower and a splendid garden variety. Field grown roots, each, 75 cents; green plants, each, 50 cents.

Planet (Cactus). White at base of florets, changing to rosy pink, the whole spotted and striped with scarlet. Flowers large and of typical, neat, incurved exhibition form. Without doubt one of the best fancy cactus. Tubers, each, 75 cents; green plants, each, 50 cents.

Polar star (Decorative). Very pure, glistening white flowers on long stems. Tubers, each, \$1.00; green plants, each, 75 cents.

Pride of California (Decorative). A cross between Mina Burgle and Souv. de Gustave Douzon with the qualities of both parents. Color a crimson red with dark, full center; huge flowers on long perpendicular stems. Well rooted plants, each, $\$ \mathbf{\$ 1 . 0 0}$.

Princess Mary (Decorative). Vivid light pink, margined blush; very showy; carries a mass of flowers on stiff stems, but requires disbudding to produce best results. Field grown roots, each, 50 cents.

Red Cross (Hybrid Cactus). A large flower of a shape similar to the renowned Kalif, but with somewhat longer petals. The color is yellow, suffused with scarlet in such a way that the effect at first sight is bronzy yellow or salmon. Stiff stems. Green plants only, each, \$2.00. 
Ruth Gleadell (Hybrid Cactus). A fine hybrid of sunburst shades; soft yellow shading to pink on the outer petals. Good stem, large size, excellent formation and a free bloomer. Well rooted green plants, each, \$1.00.

San Francisco (Hybrid Cactus). Immense flowers of a reddish bronze, petals broad and twisted, carried on upright rigid stems, high above the foliage. Well rooted plants, each, 75 cents.

Seahorse (Hybrid Cactus). An English novelty of splendid erect habit and very free flowering. The blooms are of medium size, golden yellow with pure white tips, these often spreading half-way down each petal. Very beautiful. Green plants, each, \$1.25.

Searchlight (Cactus). A yellow form of the variety "Miss Stredwick," the plants being very similar in growth and habit. Flowers large and beautifully, though not excessively, incurved in form, and the florets are narrow throughout their length. Green plants, each, 50 cents.

Seraphine (Peony). Large flowers of a peculiarly bright, clear yellow on long, stems. Field grown roots, each, 50 cents; green plants, each, 35 cents.

Sulphurea (Decorative). One of the earliest to bloom. Sulphur yellow, with long petals throwing back like a Japanese chrysanthemum. Blooms are large and very free. Green plants, each, 50 cents.

Sweet Brier (Cactus). An exquisite shade of rose pink. One of the best pink cactus Dahlias obtainable. Medium size. Green plants, each, 35 cents.

Terra Cotta (Decorative). A very good decorative, full petalled, carried on stiff upright stems and of a beautiful, soft, rosy terra cotta color. Field grown roots, each, 50 cents; green plants, each, 35 cents.

The Giant (Peony). This is truly a giant-flowering Dahlia. It is a strong grower, and if heavily disbudded the flowers are enormous. The color is deep crimson, almost maroon. Blooms freely and is one of the best peony flowered Dahlias grown. Strong, thrifty green plants, each, \$1.00. 
The Grizzly (Decorative). A dark maroon red of enormous size and great depth. A prolific bloomer with long, stiff stems. First class exhibition variety. Well rooted plants, each, $\$ \mathbf{2 . 0 0}$.

The Iion (Cactus). A large flower of bronze oldrose, suffused with yellow and salmon. Green plants, each, 35 cents.

Tom Iundy (Hybrid Cactus). An exceptionally good hybrid, though it frequently reverts to the peony type when it is just as pretty as when true to form. Easily grown to measure nine or ten inches across; color rich crimson with violet reflex. Carried well above the foliage. Field grown roots, each, 75 cents.

Van Dyke (Peony). One of the most popular of all the peony flowered Dahlias. Flowers are very large and are carried well above the foliage on long, strong stems. Color salmon, shaded heliotrope. Green plants, each, 50 cents.

Vicar of wasperton (Cactus). A large and good variety, cream at the center and changing to pink at the tips of the long, claw-shaped petals. Green plants, each, 50 cents.

Walta Iinforth (Peony). A big Dahliz of an uncommon, odd shade of warm carmine. Freely borne on long stems. Well rooted plants, each, $\$ \mathbf{1 . 0 0}$.

washington (Cactus). Flowers are very large and of pronounced incurved form, both broad and deep. Good habit, very free flowering, the blooms being borne on long, wiry stems. Deep crimson, one of the best. Field grown roots, each, $\mathbf{\$ 1 . 0 0 ;}$ well rooted plants, each, 75 cents.

Weber (Peony). An immense rose-pink flower, quite single in type, but almost the size of a dinner plate. Five or six of these with a little green make as fine a bouquet as one could desire. Stems slender, but very long and stiff. Field grown roots, each, 75 cents; green plants, each, 50 cents.

Yellow King (Hybrid Cactus). One of the very largest of its class. Chrome yellow flowers with long 
twisted and curled petals borne on long, stiff stems. Fittingly named and well worth growing for either garden use or exhibition. Field grown roots, each, 75 cents; green plants, each, 50c.

Zouave (Peony). A large flower of a rich crimson not quite as dark as Holman Hunt. A very profuse bloomer which seems to do best in dry seasons. Field grown roots, each, 50 cents.

\section{BARGAIN COUNTER}

Under this heading I am grouping a number of good, though inexpensive, varieties. Your choice, while they last, 25 cents each; $\$ 2.00$ per dozen. Tubers only:

Achievement. Collarette Maroon, white collar.

Benedictus Xv. Decorative. Bright yellow, very full.

Cassandra. Peony. Soft rosy-orange.

Chatenay. Peony. Salmon.

Cuban Giant. Show. Deep Maroon, immense.

Frank Smith. Show. Small, purplish maroon, tipped white.

Geisha superba. Peony. Scarlet and orange.

Fierald. Collarette. Rose-pink, white collar.

Mina Burgle. Decorative. Brilliant scarlet, very free.

Masterpiece. Peony. Orange, darker center, long stems.

Mabel. Decorative. Mauve pink and white.

Marguerite. Peony. Pure white, free bloomer.

Mme. Fevriere. Decorative. Lavender and white.

Naomi. Peony. Rosy pink.

Phidias. Peony. Pink on yellow ground, long stems. Rheinkonig. Hybrid Cactus. Pure white.

Royal Purple. Show. Deep purple, large and good. Souv. De Gustave Douzon. Dec. Bright red, immense.

Titian. Peony. Rose, shaded darker.

Yellow Transparent. Single. Dwarf, for borders. 
